\title{
The Exploration on Cooperative Educational Teaching of Electronic Information Engineering Major
}

\author{
Faquan Yang / Foshan University \\ School of Electronic Information Engineering \\ Foshan, China \\ Yafaquan.fosu@163.com \\ Yuexia Zhao / Foshan University \\ School of Electronic Information Engineering \\ Foshan, China \\ Yuexia@163.com \\ Lijun Feng / Foshan University \\ School of Electronic Information Engineering \\ Foshan, China \\ Lijun@163.com
}

\author{
Yonghao Xiao/ Foshan University \\ School of Electronic Information Engineering \\ Foshan, China \\ Xiaoyonghao@163.com \\ Jianwen Chen / Foshan University \\ School of Electronic Information Engineering \\ Foshan, China \\ Jianwen.edn@163.com \\ Qingfeng Cai / Foshan University \\ School of Electronic Information Engineering \\ Foshan, China \\ Qingfeng.edn@163.com
}

\begin{abstract}
According to the 2017 human resource training plan, this paper reflects the cooperation with the cooperative education teaching company in exploring the theoretical course of collaborative education for electronic information engineering major, the design of professional integrated curriculum, and the construction of practical base. In addition, this paper also presents the exploration and reform in teaching content, teaching method, and course assessment system, which can help to further cultivate students' creative ability, practical ability and employment competitiveness. The practice indicates that the teaching reform courses carried out through collaborative education method are very popular among students and have achieved good teaching effect.
\end{abstract}

Keywords-Electronic information engineering major; Cooperative education; Cultivation of human resources; Exploration of teaching

\section{INTRODUCTION}

With the rapid development of China's economy and the adjustment and upgrading of the industrial structure, there is an increasing demand for talents in the society. How to cultivate applied talents effectively is a major task for many application-oriented colleges and universities[1].

In recent years, the practical experience of reform and development of education shows that the cultivation of high quality applied talents must follow the path of running school open and cooperation of school-enterprise. Especially for electronic information majors, the teaching content of their courses often lags behind the development of the electronic information industry. Therefore, it is necessary to do the reform on the training mode of electronic information majors and adhere to the concept of "in-depth cooperating between universities and enterprises, oriented to the electronic information industry, and cultivating application-oriented talents". By integrating the teaching system, we will deepen the reform of education and improve the mechanism of collaborative education. Through constructing the practice platform and teaching team, we can solve the shortage of practical teaching resources and "dual teacher" teachers. Therefore, it is an important way to train application-oriented talents with high-quality through industry-university-research cooperation[2].

\section{COOPERATIVE EDUCATION}

\section{A. The Meaning of Cooperative Education}

Cooperative education refers to the mix of production, education and pre-job training through integrating different education resources such as colleges, enterprises and institution while giving full play to different parties' advantage in talents cultivation. It keeps the cultivation of creative talents as the central task, targets at improvement of competiveness of employment and the comprehensive cultivation of students' quality and comprehensive ability. In addition, it is a new talents cultivation mode of training high quality professional innovative talents for the society [3] 


\section{B. Cooperative Education Plays an Important Role in Cultivating High Quality Applied Talents}

First of all, carrying out the cooperative education is helpful to improve the quality of talent training. Collaborative education of production as a new type of talents training mode emphasizes training the professional application-oriented talents requires co-culture among universities, enterprises and society. In the process of talent training, it is necessary to adhere to the combination of theory and practice, break the traditional teaching mode, and keep cultivation of students' practice ability and innovation ability as the basic point and starting point. Therefore, it is beneficial to improve the quality of personnel training and enhance students' social adaptability and employment competitiveness.

Secondly, the development of collaborative education is conducive to accelerating the construction of "double-teacher" teachers. The central problem of teaching in applicationoriented universities is the cultivation of application-oriented talents. A team of "double-teacher" teachers with strong comprehensive practical ability is indispensable in cultivating application-oriented talents. Part-time teachers are an important part of "double-teacher" teachers in colleges and universities [4]. By carrying out the teaching practice activities of industry-university-research cooperation in educating people, we can also employ skilled craftsmen in this region and this industry to serve as practical teachers, which is conducive to accelerating the "dual teacher" model.

Thirdly, the development of collaborative education is conducive to stimulating the students' innovative consciousness. The cultivation of college students' innovative consciousness is the basic goal of cultivating applicationoriented talents of higher education. The so-called innovative talents refer to those who have the spirit of innovation, innovation ability and practical ability. They are those who have the ability or potential to discover new problems, solve new problems, invent new things and create new fields [5]. Through carrying out the teaching practice of collaborative education, the training program for the collaborative education of professionals in this major is formulated in this paper, which helps to train innovative talents with thick foundation, wide caliber, strong ability, high quality and coordinated development of knowledge and ability. This program faces to Foshan city and even Guangdong province. Therefore, developing the collaborative education model is conducive to stimulating students' innovative consciousness.

Fourthly, the development of industry-university-research collaborative education is beneficial to solve the problem that engineering education is out of line with production practice [6].

At present, due to the influence of the traditional education model, the higher engineering education focus more on the theory and neglect the practice. During the teaching process, the students is required to master knowledge without the cultivation of student's innovation consciousness and innovation ability, which makes the higher engineering education out of line with the actual production practice and leads to poor engineering practical ability for most of the engineering students. Carrying out industry-university- research collaborative education is beneficial to solve the problem that the project education is out of line with the production practice.

\section{SPECIFIC IMPLEMENTATION OF PROFESSIONAL COLLABORATIVE EDUCATION}

\section{A. Setting up the Teaching Guidance Committee for the Collaborative Education of the Major}

In order to quicken the pace of the collaborative educational exploration on the electronic information engineering major in our university, a collaborative educational teaching guidance committee composed of the university and the cooperative unit personnel was established. The leader of the committee was the principle of the university (the dean of the department), and the deputy leader was the training director of the enterprise(pre-job training director). The responsibility of the teaching guidance committee of collaborative education is to participating in the formulation of professional talent training programs, and the establishment of collaborative curriculum.

\section{B. We Will Strengthen the Construction of a Teaching Team of "Double-Teacher" School-Enterprise Collaborative Education}

For education teaching team construction of "double teacher" synergy between colleges and enterprise, "please come in and go out" is adopted. On the one hand, first-line technical staff of enterprise are employed as teachers who focus on campus practice curriculum. On the other hand, in the holiday, a professional teacher will be send to the enterprise to participate in the professional training, enterprise technology research and development, which can improve teachers' engineering practice ability.

\section{We Will Strengthen the Construction of a School- Enterprise Collaborative Education Base}

In order to strengthen the construction of the schoolenterprise collaborative education base, according to the teaching requirements for cultivating applied talents, the teaching team members including both the school and enterprise should build the practical training base through integrating the practical teaching resources from both sides.

D. In the Program of Cultivating Talents of Electronic Information Engineering Majors, a Pilot Program of Collaborative Education Was Carried out to Select Courses That Are More Relevant to Professional Development Ability, Which Can Advance the Practical Teaching Reform of Collaborative Education for Electronic Information Majors.

The professional courses planned in the training program for electronic information engineering majors include professional basic courses and professional courses. The professional basic courses and professional courses contain compulsory courses and elective courses. However, all the offered professional courses can be classified into two types of professional courses, which are mainly learning knowledge 
and cultivating abilities. Considering the cost and effect of collaborative education, we choose specialized courses which focus on cultivating ability and are used as the experimental courses of collaborative education. The specialized courses can be embedded development and application, APP development and application, professional integrated curriculum design and graduation design, etc. In cooperative education, we combine theory teaching with practice training in accordance with the cognitive requirements of "theory practice - theory - practice". In particular, students are trained to find problems, analyze problems and solve problems through the practical activities of education such as the graduation design. Through the production practice activity, the student's study interest and ability in following up the course can also be improved.

\section{E. Directing on Cooperation Training and Recommending Employment}

According to the program of cultivating talents of electronic information engineering majors, principle of voluntariness, and the combination of the standard needs in enterprise talents and the job qualification, the students from different professional direction in our major are chosen to different pre-training teams.

\section{TARGETED COLLABORATIVE TRAINING, RECOMMENDED EMPLOYMENT}

(1)Students Have a High Degree of Recognition for the Pilot Courses of Collaborative Education, and the Statistics of Students' Satisfaction with the Courses are Shown in Table 1.

TABLE I. SURVEY OF COOPERATIVE EDUCATION COURSE SATISFACTION

\begin{tabular}{|c|c|c|c|c|}
\hline $\begin{array}{c}\text { Classes of investigation } \\
\text { and projects }\end{array}$ & Very satisfaction & Satisfaction & The general satisfaction & No satisfaction \\
\hline 2014 electronic class $1(43)$ & 15 & 26 & 2 & 0 \\
\hline 2014 electronic class $2(45)$ & 17 & 24 & 3 & 1 \\
\hline 2015 electronic class $1(41)$ & 11 & 26 & 4 & 0 \\
\hline 2015 electronic class $2(39)$ & 14 & 23 & 1 & 1 \\
\hline $\begin{array}{l}\text { The number of } \\
\text { statistics(168) }\end{array}$ & 57 & 99 & 10 & 2 \\
\hline Proportion (average) & $34 \%$ & $59 \%$ & $5.9 \%$ & $1.1 \%$ \\
\hline
\end{tabular}

(2)Through the Cooperative Education, Students' Innovation Ability has been Significantly Improved. The Number of Winners in the Electronic Design Competition that Reflects Students' Innovation Ability and the Number of
Students Who Have Applied for Students' Innovation Projects after Cooperative Teaching Have Increased, as Shown in Table 2and Table 3:

TABLE II. SURVEY OF ELECTRONIC DESIGN COMPETITION WINNING

\begin{tabular}{|c|c|c|c|c|}
\hline Year and projects & Third prize of provincial & Second prize of provincial & First prize of provincial & National prize \\
\hline 2015 & 8 & 2 & 0 & 0 \\
\hline 2016 & 12 & 6 & 5 & 2 \\
\hline 2017 & 17 & 8 & 6 & 3 \\
\hline 2018 & 23 & 13 & $100 \%$ & $100 \%$ \\
\hline $\begin{array}{c}\text { The growth rate of 2018 } \\
\text { compared to 2015 }\end{array}$ & $65 \%$ & $84.6 \%$ & $66.7 \%$ & $66.7 \%$ \\
\hline $\begin{array}{c}\text { The growth rate of } 2018 \\
\text { compared to 2016 }\end{array}$ & $47.8 \%$ & $53.8 \%$ & $16.7 \%$ & $33.3 \%$ \\
\hline $\begin{array}{c}\text { The growth rate of } 2018 \\
\text { compared to 2017 }\end{array}$ & $26 \%$ & $38 \%$ & & 2 \\
\hline
\end{tabular}


TABLE III. SURVEY OF UNIVERSITY STUDENT INNOVATION PROGRAM

\begin{tabular}{|c|c|c|c|}
\hline Year and projects & School level & Provincial level & National level \\
\hline 2015 & 4 & 2 & 2 \\
\hline 2016 & 10 & 5 & 4 \\
\hline 2017 & 16 & 10 & 5 \\
\hline 2018 & 25 & $80 \%$ & $60 \%$ \\
\hline $\begin{array}{c}\text { The growth rate of 2018 compared to } \\
2015\end{array}$ & $84 \%$ & $50 \%$ & $40 \%$ \\
\hline $\begin{array}{c}\text { The growth rate of 2018 compared to } \\
2016\end{array}$ & $60 \%$ & $20 \%$ & $20 \%$ \\
\hline
\end{tabular}

(3)After Collaborative Education, the Employment Competitiveness of Students Has Been Significantly Improved, Among Which the Initial Employment Rate and Salary Reflecting the Employment Competitiveness Have Been Greatly Improved.

\section{CONCLUSION}

This paper explores the teaching concept, teaching course and the method of implementing collaborative education for electronic information engineering majors. This program is carried out among the three classes of students of electronic information engineering in 2013, 2014 and 2015. The practical effect of collaborative education shows that the curriculum reform carried out by the method of collaborative education is very popular among students, and students have improved their innovation ability, practical ability and the competitiveness of employment. Therefore, good teaching effect has been achieved.

\section{ACKNOWLEDGMENT}

The authors wish to thank my classmates and friends in our laboratory in X'idan University such as Dr. Zhongxian PAN, Xinyin XIANG, Ganchao LIU, Dr. Jie Zheng et al. This work was supported by a grant from my work affiliation: school of electronic information engineering, Foshan University. In this paper, the research was sponsored by the professional comprehensive reform project of electronic information engineering of Foshan University.

\section{REFERENCES}

[1] A. Van, C. J. Mcnewbirren, E. W. Eckman, et al, "Field Experience as the Centerpiece of an Integrated Model for STEM Teacher Preparation," Teacher Education \& Practice, vol.26(2), pp.339-355,2018.

[2] X. Z. Yang, L. L. Xiao, L. I. Yun-Yu, "Exploration and Practice on Teaching-research-production Cooperative Education to Electronics Majors,"Education Modernization, vol.36(4), pp.218-224,2018.

[3] Z. X. Liu, Y. W. Wang, "Thinking on the Problems of Classroom Teaching and Practical Teaching_-Taking the Sino Foreign Cooperative Education Project of Guangxi University For Nationalities as An Example," Education Teaching Forum, vol.56, pp. 328-332, April 2018.

[4] F.Q. Yang, "Communication systems modeling and simulation in MATLAB”, Tsinghua university press, Beijing, 2015, str. 213-315.

[5] X. D. Pan, Q. M. Zhang, "The Current Situation of Foreign Language Teaching from the Perspective of SinoForeign Cooperative Education Projects at the Undergraduate Level — Taking Non-English Countries as an Example," Education Modernization, vol.75(5), pp. 559-555, 2018.

[6] H. Yan "Reflections on the Mode of Sino Foreign Cooperative Education," Education Teaching Forum, vol.32(8), pp. 168-172, 2018. 